\title{
A nyelvi fejlődés folyamata, az eltérő nyelvi fejlődés korai felismerése és terápiája
}

\section{Rosta Katalin}

ELTE Gyakorló Óvoda és Egységes Gyógypedagógiai Módszertani Intézmény

\begin{abstract}
A nyelv az emberek közötti kommunikáció eszköze. A nyelvi fejlödés minősége meghatározó az ember életében. A nyelv hidat alkot az emberi kapcsolatokban (kommunikációban), része a tanulás, az ismeretszerzés folyamatának, a gondolatok kifejezésének. Az anyanyelvünket a környezettöl kapott nyelvi minta alapján sajátítjuk el. Írásomban az anyanyelvfejlödés életkori sajátosságait, a nyelvi elmaradások formáit, pedagógiai vizsgálatát és terápiáját mutatom be, felvázolom a megelőzés és az otthoni segítségnyújtás lehetőségeit, nem foglalkozom azonban az eltérő nyelvi és kulturális szocializációból következő nyelvfejlődési problémákkal.
\end{abstract}

Kulcsszavak: anyanyelv-elsajátítás, megkésett nyelvfejlődés, állapot-megismerés, korai fejlesztés, beszédprodukció

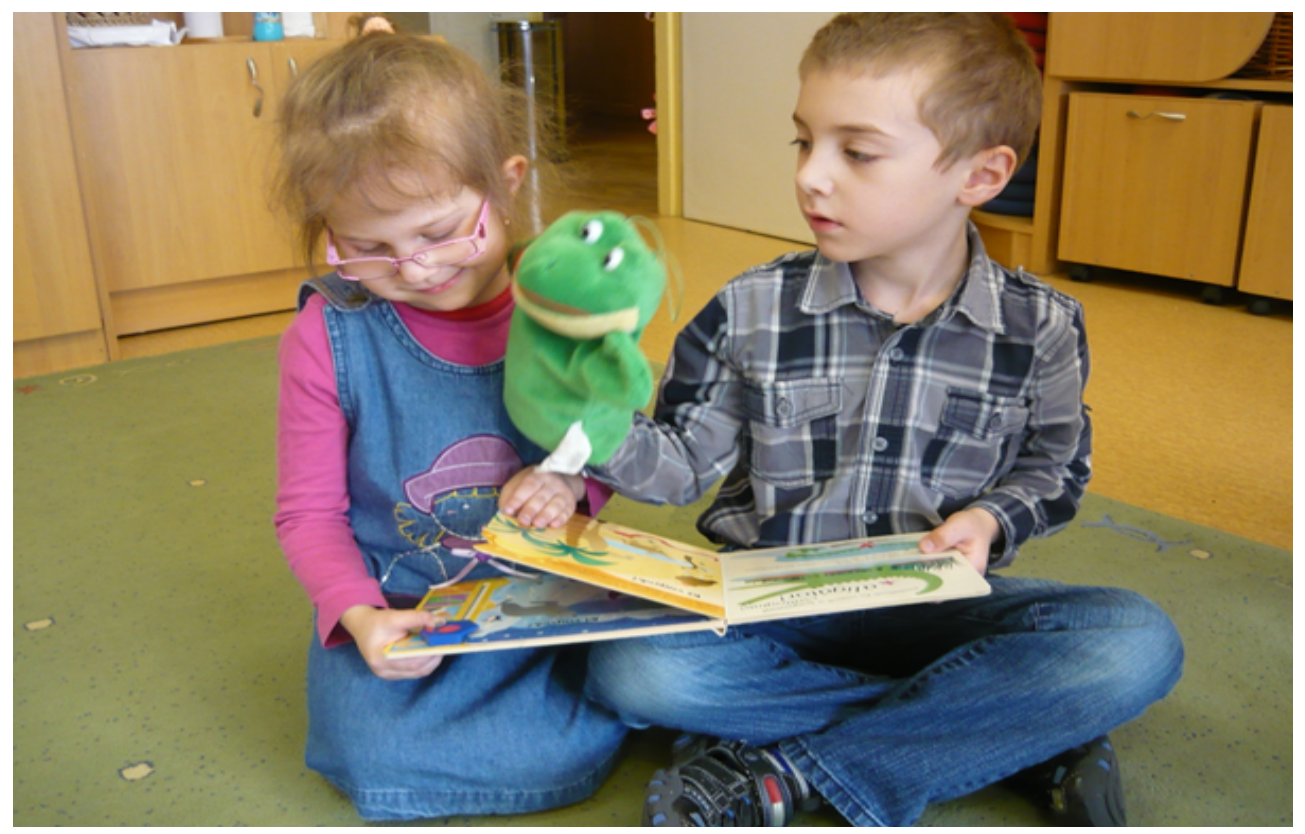

1. kép: Kommunikációs helyzet gyermekek között

\section{Bevezetés}

A gyermek az anyanyelv elsajátítása során olyan képességek birtokába jut, amelyek segítségével alkalmassá válik gondolatainak megformálására és átadására. A nyelv, a beszéd az ember természetes, magától értetődőnek tűnő kommunikációs képessége. Az anyanyelv elsajátítása általában spontán történik, a fejlődés egy szakaszának eredményeképpen tudunk anyanyelvünkön megszólalni, vagy az elhangzott beszédet megérteni, felismerni.

A 21. században a nyugati típusú társadalmakban a nyelvi kifejezőképesség megléte, a kommunikáció színvonala a gyermekek fejlődésében és a felnőttek életminőségében meghatározó jelentőségű. A nyelv az emberek közötti kommunikáció eszköze, 
az információtárolásnak és rendszerezésnek csak az emberre jellemző sajátossága. Az alap kultúrtechnikák (olvasás, írás, számolás) elsajátításának sikeressége szorosan öszszefügg az anyanyelv elsajátításával, befolyásolja az iskolai sikerességet. Az anyanyelv elsajátítása azonban nem minden esetben problémamentes, a nyelvi kommunikációs képesség elmaradásának a legkülönfélébb organikus, funkcionális, pszichés és környezeti okai lehetnek. Írásomban megpróbálom felvázolni az anyanyelv-elsajátítás tipikus folyamatát, majd bemutatom az eltérő kisgyermekkori nyelvfejlődést, és végül szólok néhány szót a megelőzés és a terápia lehetőségeiről.

\section{A beszédészlelés és beszédprodukció elsajátítása}

A nyelv elsajátítása hosszú folyamat eredménye. A méhen belüli életben a magzati nyelv kialakulásával veszi kezdetét és kb. 14 éves korban éri el a felnőttkorra jellemző nyelvi fejlettségi szintet. Az anyanyelv-elsajátítás, vagyis a beszédészlelés és -megértés az újszülöttkorban kezdődik és folyamatosan fejlődik. A csecsemők születésüktől kezdve értelmezik a környezet hangjait, és az első pillanattól kezdve alkalmasak a beszédfeldolgozásra, a kommunikációra. A háromnapos csecsemők felismerik az édesanyjuk hangját, kéthetesen pedig már képesek az emberi hangot más hangtól (pl. csengő, kutyaugatás) elkülöníteni. Az újszülöttkortól meglévő kifejező sírás már egyfajta kommunikáció, a gyermek jelzéseket küld a környezetének az állapotáról (pl. éhségsírás, fájdalomsírás). A kifejező sírás részleges funkcióvesztését a gőgicsélés, gagyogás megjelenése idézi elő. A gagyogásnak meghatározó szerepe van a beszéd kialakulásában és fejlődésében, mivel ez a beszédprodukció fejlődésének első állomása. A 6-9 hónapos csecsemő már kommunikációs céllal gőgicsél. A csecsemő az első életév során begyakorolja azokat a hangképző szervekhez kapcsolódó mozgássorokat, amelyek a beszédhangok létrehozásához szükségesek. Az első szavak (kb. egyévesen) azokból a hangokból épülnek fel, amelyek a gyermek gagyogása során kialakultak (Fehérné Kovács és Sósné Pintye, 2010). A gyermekek első szavai 10-15 hónapos kor körül jelennek meg, de már ez idő előtt is megértenek néhány szót, utasítást (pl. „papa”, „mama”, „megyünk!”). A gyermekek egyéves kor tájékán fedezik fel, hogy a szavak segítségével fel tudják kelteni a környezet figyelmét, és cselekvésre tudják késztetni a felnőtteket: vö. illokúciós és perlokúciós aktus (Austin, 1990). A gyermekek általában másfél éves koruk tájékán jönnek rá arra, hogy mindennek neve van. Ekkor az eddig lassú szótanulási folyamat ugrásszerüen felgyorsul, bekövetkezik a szórobbanás. Az első szavak általában alapszintű kategóriákat jelölnek (pl. kutya, kocsi). Az első szavakkal a gyermek egy egész gondolatot is kommunikálhat, teljes mondatot jelölhet, ezért ezt a fejlődési szakaszt az egyszavas mondatok korszakának, vagyis „holofrasztikus szakasznak” nevezzük (Lukács és Kas, 2011). A holofrázisok szakaszát a kétszavas, majd a többszavas közlések megjelenése követi. A gyermek fokozatosan birtokba veszi és alkalmazza a magyar nyelv fonológiai, alaktani és morfológiai jellemzőit, szabályait, ezzel párhuzamosan biztosabbá válnak a beszédhangot létrehozó artikulációs mozgások (Gósy, 2007). A harmadik életév tájékán kialakulnak a 4-5 tagú közlések, a gyermek kezd szabályosságokat felfedezni a nyelvben. A gyermek szókincse folyamatosan bővül, a mondattani szerkezetek bonyolultabbá válnak. Ebben az életkorban a kisgyermekek képesek lesznek a nyelv segítségével kifejezni érzéseiket, információt szerezni, a környezettel verbális kapcsolatot kialakítani. A gyermekek 4 éves korukban már összefüggően beszélnek, jelentősen fejlődik a szófelismerésük, egyre helyesebben használják a nyelvi toldalékrendszert, kialakul az időbeliség fogalma. Az 5 éves gyermekek beszédében az összes szófaj és alaktani jelenség előfordul, grammatikai rendszerhasználatuk folyamatosan fejlődik, szívesen és sokat kommunikálnak. A nyelvi képesség 
a személyközi kapcsolatokon, a kommunikáción keresztül fejlődik, ezért a gyermekek beszédmegértésében fontos szerepe van az előzetes tapasztalatoknak, az érzelmeknek, az események sorrendjének és a beszéd feldolgozási gyakorlatának. A gyermek nyelvi fejlettségét meghatározza az, hogy környezetétől milyen beszédmintát és mennyi nyelvi ingert kap. A fejlődés a hangképzés, a jelentés, a grammatika és az interakciós képességek területén, együttesen fejlődik. A későn felfedezett nyelvfejlődési problémák nehezítik a gyermek fejlődését és fejlesztésének esélyeit.

Az iskoláskor kezdetére a gyermekeknek rendelkezniük kell az alap kultúrtechnikák (olvasás, írás, számolás) elsajátításához szükséges nyelvi fejlettséggel (szókincs, grammatika, szövegalkotási képesség, beszédértés és -észlelés), illetve ki kell, hogy alakuljon a fonológiai tudatosság, azaz a szavak hangokra történő bontásának képessége.

\section{A nyelvfejlődési elmaradás}

Az anyanyelvét minden egészséges gyermek képes elsajátítani. A nyelv elsajátításának egyes szakaszai minden gyermekre egyformán jellemzőek. Egy-egy gyermek nyelvi fejlődése azonban egyénenként változó lehet, eltérhet a szabályostól. A gyermek nyelvi fejlődését, nyelvelsajátítását meghatározzák biológiai adottságai (genetikai öröksége), kognitív és szociális képességei, valamint környezetének kommunikációs szintje. A gyermeki beszéd fejlődéséhez és megtanulásához szükség van a megfelelő észlelési teljesítményre is. Normális körülmények között a gyermekek nyelvelsajátítása az egyénre jellemző ütemben történik, egyesek az átlagosnál gyorsabban, mások lassabban fejlődnek. Az átlagtól eltérő, lassan fejlődő gyermekeknek és családjaiknak segítségre van szükségük. A nyelvi fejlődési zavarok korai felismerése, az időben nyújtott segítség döntő fontosságú, mert a nyelvi fejlettség szintje befolyásolja az egyéni életutat. A nyelvi elmaradás esetén a gyermekeknél feltűnő lehet, hogy nem figyel a környezetének hangjaira, késhet a beszédindulás időpontja, az életkorban elvárhatónál lassabban fejlődik a gyermek beszéde (pl. 3 éves és csak 5-10 szavas szókincse van), vagyis minőségi és mennyiségi eltérést mutat az életkorban elvárható beszédszinttől.

Az eltérő fejlődés hátterében a legkülönbözőbb okok állhatnak, akár a különböző biológiai adottságok (pl. az agyi érési folyamat milyensége), akár a környezeti hatások (a család nyelvi, kulturális szintje), esetleg a szociális interakció zavara. Az eltérő fejlődés felismerése, kiszűrése és nyomon követése az első életévekben a védőnő és a gyermekorvos feladata volna, hiszen ők állnak a legszorosabb kapcsolatban a családdal. Sajnos azonban a nyelvfejlődési elmaradások esetén még mindig elterjedt a „majd kinövi” szemlélet, ami akadályozza, hogy a segítségre szoruló gyermekek időben megkapják az optimális fejlődésükhöz szükséges segítséget. Reméljük, hogy a jelen pozitív irányú törekvései, vagyis az egészségügyi alapellátásban dolgozók képzése változtat ezen a szemléleten.

\section{A nyelvi fejlődés zavarai}

A gyermek gyenge beszédteljesítménye mögött a különböző nyelvi szintek (fonológiai, morfológiai, szintaktikai, lexikai, szemantikai) müködésének eltérése vagy deficitje húzódhat meg. A nyelvi zavarok különböző formái jelentkezhetnek önmagukban vagy valamely más fejlődési zavarhoz kapcsolódóan. A nyelvi zavarok egy részének oka a gyermekben rejlik. Az egyéni képességdeficitek közé tartozik a genetikai vagy egyéb kóreredetű általános fejlődési zavar (pl. Down-szindróma), a szenzoros zavarok (pl. hallássérülés) és/vagy a szociális zavarok (pl. autizmus). A gyermekek másik csoportjánál specifikusan jelenik 
meg a nyelvi zavar anélkül, hogy a zavart kognitív, szenzoros vagy környezeti okokkal magyarázhatnánk. Ezt a zavart specifikus nyelvi zavarnak, szakirodalmi rövidítéssel SLI-nek nevezzük (Lukács és Kas, 2011). A specifikus nyelvi zavart mutató gyermekek nyelvi fejlödése már a korai életkorban eltér az átlagostól. Az első szavak a normális beszédfejlődéshez viszonyítva 2-3 évvel később jelennek meg, szókincsük lassan fejlődik. Szótalálási és szóaktivizálási nehézségeket figyelhetünk meg náluk. A gyenge nyelvi produkcióhoz az esetek nagy részében beszédmegértési nehézség is társul (Gósy, 2007).

„A nyelvi zavar sokarcú jelenség, tüneti csoportositása több szempontból lehetséges. Az érintett nyelvhasználati területek alapján megkülönböztethetünk receptív (megértési) és expresszív (kifejezési) zavarokat. Az érintett nyelvi szintek alapján fonológiai (a beszédhang feldolgozását vagy használatát érintő), lexikai (a szókincs területén jelentkező), szemantikai (a jelentésben megmutatkozó), morfoszintaktikai (nyelvtani) és pragmatikai (nyelvhasználati) zavarokat." (Lukács és Kas, 2011. 213. o.)

A nyelvi zavarok lehetnek enyhébbek vagy súlyosabbak, az elvárt életkori szinttől történő eltérés függvényében.

\section{A nyelvi fejlődés zavarainak felismerése és megismerése}

A nyelvi fejlődési elmaradás időben történő felismerése sok esetben nehéz, ha a gyermek általános fejlődése egyébként az életkorának megfelelő. Még mindig találkozunk a már említett „majd kinövi” szemlélettel, a szülők nemegyszer azzal indokolják várakozásukat, hogy „az apja is későn kezdett beszélni”. Pedig a probléma korai felismerése és az időben nyújtott segítség döntő jelentőségủ a gyermek optimális fejlődése érdekében, és a másodlagos problémák (pl. evészavarok, magatartászavarok) megelőzésében.

Mint ahogy fentebb írtam, a fejlődési szürés a védőnő és gyermekorvos feladata volna, akik a probléma felfedezése után a gyermeket szakemberhez, logopédushoz irányíthatják. Tapasztalataink alapján azonban a korai fejlesztésre jelentkező gyermekek nagy részénél a család vagy a környezet fedezi fel a problémát, kisebb részüknél az - organikus sérülések vagy fejlődési rendellenességek esetében - a szakorvos irányítja csak fejlesztésre a gyermeket. Megjegyezném, hogy a ma kialakult gyakorlat az, hogy a szülök a „korai fejlesztő központokban” jelennek meg először a problémáikkal. A korai fejlesztésre jelentkező családoknál a szakemberekből álló team (logopédus, pszichológus, esetenként gyógytornász vagy szomatopedagógus) munkája a panasz felvételével kezdődik, amely során meghallgatják a szülőket a gyermek nyelvi fejlődésével kapcsolatos aggodalmaikról. Ezután következik az alapos, a kommunikáció fejlődését és fejlettségi állapotát feltáró anamnézis, mely kiterjed a gyermek beszéden kívüli fejlödésmenetének feltárására is. A szakemberek a találkozás során megfigyelik a gyermek viselkedését, érdeklődését a tárgyak és az emberek iránt. Ezenkívül játékos helyzeteket teremtve megfigyelik a gyermek kommunikációját a szüleivel, továbbá fel kell mérniük a gyermek figyelmi állapotát és temperamentumát. A megfigyelés fontos része a szülö-gyermek, anya-gyermek kapcsolat feltérképezése is. A játékos helyzetekben tájékozódnak a szülő nevelési stílusáról, kulturáltságáról, nyelvhasználatáról, az esetleges szociális hátrányt kiváltó személyi okokról.

Ezután a szakemberek az adatokat értelmezik, és elemzik a gyermek nyelvi állapotát, kommunikációs készségeit és pszichés fejlettségét. Az ismeretek birtokában eldöntik a további vizsgálatok szükségességét (pl. hallásvizsgálat, foniátriai vizsgálat), és a gyermeket szakértői bizottsághoz irányítják a képességprofil és beszédállapot részletes feltárása érdekében (Rosta, 2006). A jelen gyakorlat szerint azonban a vizsgálatra hónapokat kell várni, így értékes idő esik ki a gyermek fejlesztéséből. 
Problémát jelent még az is, hogy a 15/2013 (II. 26.) EMMI rendelete a pedagógiai szakszolgálati intézmények müködéséről lehetőséget biztosít a gyermekek fejlesztésére 0-5 éves korig a gyógypedagógiai tanácsadás, korai fejlesztés, oktatás, gondozás keretein belül, azonban ha a gyermek intézményes ellátásban részesül, azaz óvodás lesz, az elkezdett korai fejlesztő munka megszakad, a gyermek fejlesztéséröl a továbbiakban az őt ellátó intézmény szakemberei vagy utazó pedagógusok, logopédusok gondoskodnak, illetve súlyos beszédprobléma esetén a gyermeket logopédiai óvodai ellátásban részesítik.

Mivel a nyelvi fejlődés elmaradását jó esetben 2 éves kor tájékán fedezik fel, ekkor válik nyilvánvalóvá a környezet számára, hogy a gyermek egyáltalán nem vagy keveset beszél, így a korai fejlesztésben dolgozó szakembereknek rövid idő áll rendelkezésükre a hatékony fejlesztő munkára. Ezért a gyermek fejlődésének dinamikáját, nyelvi fejlődését a fejlesztő szakemberek csak rövid ideig tudják követni, a nyelvfejlödési zavarok terápiája során fontos folyamatdiagnózis felállítására nincs lehetőségük.

A korai életkorban fontos, a terápia sikerét meghatározó tényező még a fejlesztő szakember és a gyermek közötti biztonságos terápiás kapcsolat, a személyhez kötődés, amely a 3 éves életkor betöltése után megszakad. A harmadik életévét betöltött beszédfogyatékos (SNI) gyermekeket a szakértői bizottság kontrollvizsgálatban részesíti, és szakvéleményük alapján a gyermek további fejlesztésben részesülhet, vagy terápiája megszünik, mert beszédállapotának felmérése alapján nem minősül beszédfogyatékosnak.

Meg kell jegyeznünk azonban, hogy a hazai diagnosztikus gyakorlatból hiányoznak a korai nyelvfejlődési zavarokat vizsgáló diagnosztikus eszközök, így a nyelvfejlődési zavarok rejtve maradhatnak. Az óvodás gyermekek beszédállapotának felmérése kötelezően 5 éves korban történik meg, ez azonban az esetek jelentős részében csak a fonológiai zavarok (beszédhibák) feltérképezését, majd ezt követő terápiáját jelenti. A logopédiai vizsgálati protokoll hiánya miatt gyakran fordul elő, hogy a gyermekröl csak az iskolában derül ki, hogy nyelvi fejlődési elmaradása miatt nem tud megtanulni olvasni, írni és számolni. A problémák megelőzése érdekében a korai nyelvfejlődési elmaradásokat feltáró és a fejlődést nyomon követő vizsgálati protokollrendszer kialakítása rendkívül fontos és sürgető feladat volna.

\section{A korai segítségnyújtás szempontjai}

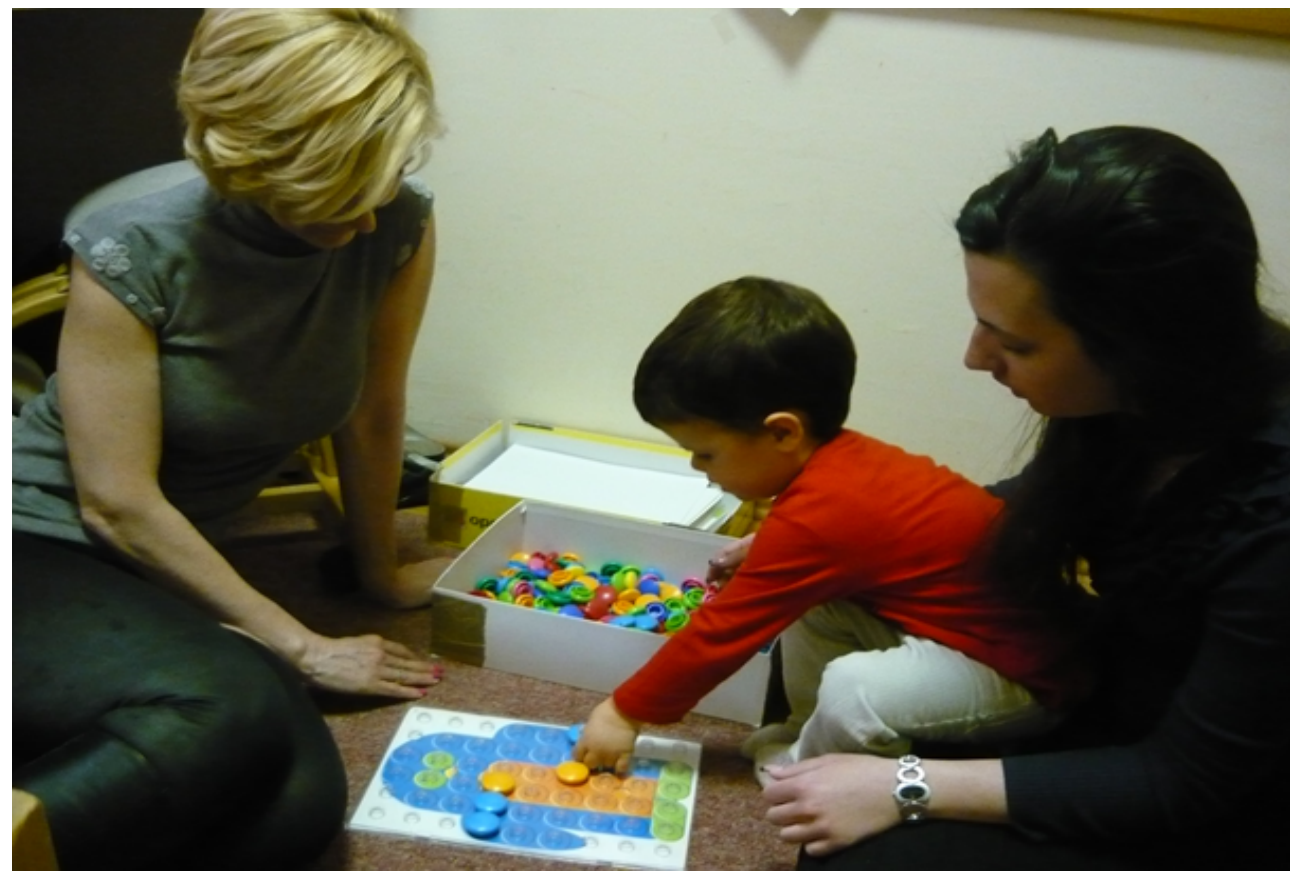

2. kép: Beszédfejlesztés szülő bevonásával 
A nyelvfejlődési elmaradás diagnosztizálása, a fejlesztésben történő részvétel jogosultságának megállapítása a szakértői bizottságok feladata. A probléma felismerésétől a diagnózis megalkotásáig azonban a gyermek fejlődése és fejlesztése szempontjából értékes hónapok vesznek el. A „korai fejlesztést” végző intézmények azonban sok esetben vállalják annak kockázatát, hogy a szakértői bizottság szakvéleménye nélkül is elkezdik a fejlesztőmunkát a gyermekek érdekében, annak a szakirodalom által alátámasztott ismeretnek a birtokában, hogy a minél korábban elkezdett nyelvi fejlesztés az igazán hatékony (Lukács és Kas, 2011). A korai segítségnyújtás a szülők, de leginkább az anyák bevonásával (ún. home-tréningben) valósul meg. A foglalkozásokon a szülö jelenléte biztonságos érzelmi hátteret nyújt a gyermeknek. A fejlesztés egyéni és/vagy csoportos foglalkozások keretében zajlik, a gyermekre kidolgozott egyéni fejlesztési terv alapján. A fejlesztés során a szakember (logopédus) megtanítja a szülőt arra, hogy a mindennapokban miképpen foglalkozzon úgy a gyermekével, hogy annak nyelvi fejlődését segítse. Éppen ezért fontos, a fejlesztés sikerességét meghatározó szempont, hogy a gyermek fejlesztését végző logopédus vagy a fejlesztő munkában közreműködő más szakember (pszichológus, gyógytornász) a szülőkkel megfelelő viszonyt alakítson ki, mert ez a gyermek érdekében végzett közös munka feltétele.

\section{A korai fejlesztés funkció-területei}

A fejlődés korai szakaszában a gyermekek pszichés fejlődése a mozgásfejlődésbe ágyazottan valósul meg. A cselekvő megismerés segíti a belső képzetek felépülését, ezáltal a nyelv fejlődését, valamint a figyelem, az észlelés, az emlékezet és a gondolkodás alakulását (Fehérné Kovács és Sósné Pintye, 2010). A gyermek nyelvi fejlődését segítő korai fejlesztő munka komplex szemléletü, és arra törekszik, hogy a mozgásos és észlelési tapasztalatok nyújtásával segítse az éntudat, a kommunikáció és a kognitív funkciók fejlődését.

\section{A motoros tevékenységek fejlesztése}

A mozgásos ismeretszerzés az alapja az idegrendszer érésének és - a tapasztalatszerzés révén - a kognitív és nyelvi fejlődésnek. Az értelmi-fogalmi műveletek eredete a cselekvésben rejlik. A mozgás öröme, a mozgásos ügyességi és egyensúlyozó játékok, a mozgásos tapasztalatszerzés fontos motivációs erőt képviselnek a gyermek fejlödésében, ezért a fejlesztésben törekednünk kell ennek kihasználására. Sok gyermeknél a terápia kezdetén - mind az egyéni, mind a csoportos fejlesztő munkában - a mozgásos játékok jelentik a kapcsolatteremtés és együttműködés első lehetőségét.

\section{A mozgással kísért beszéd fejlesztése}

A dalok, versek, mesék gesztusokkal történő elsajátítása a nem beszélő vagy keveset beszélő, megkésett nyelvfejlődésű gyermekeknek is megadja a kifejezés örömét. A játékos utánzás a kapcsolatteremtés eszköze, az első kommunikációs lépés. A mozgással kísért beszéd támogatja a beszéd megértését, fejleszti a kommunikációt segítő gesztusok kialakulását, javítja a gyermek figyelmét és verbális emlékezetét, fejleszti a mozgáskoordinációját. Az együttes élmény mind az egyéni, mind a csoportos terápia során segíti a szülő-gyermek, gyermek-szakember közötti kapcsolat kialakulását, harmonizálását. 


\section{A test tudatosságának kialakítása}

A testtudat a mozgásfejlődés, valamint a környezetröl szerzett taktilis, akusztikus és vesztibuláris ingerek sorozata, funkcionális összerendeződése révén alakul ki és válik az egyén számára meghatározóvá. A kialakult testkép, mely az önmagukról alkotott tudás alapja, az egészséges személyiségfejlődés elősegítője. Minden gyermeket hozzá kell segíteni ahhoz, hogy elégedett legyen önmagával, mert a jó érzelmi állapot pozitívan hat az énképre, ösztönzi a beszédkedvet.

\section{Az egyes érzékelési területek fejlesztése}

A környezethez történő alkalmazkodás és az ismeretszerzés fejlődésében kulcsszerepe van az észlelésnek. A korai intervenciós munka során arra törekszünk, hogy a lehető legtöbb érzékelési csatornán keresztül történjen meg a különböző érzékletek tudatosítása. A gyermek fejlődése szempontjából a legfontosabb a taktilis, vesztibuláris, kinesztetikus, látás-, hallás-, íz- és hőérzékelés fejlesztése. A fejlesztés során alkalmazott „érzékelési játékok” nagy nyelvi anyagot mozgósítanak, amely fejleszti mind a beszédmegértést, mind a beszédprodukciót.

\section{A kommunikáció fejlesztése}

A kommunikáció a szociális kapcsolatteremtés és az önkifejezés eszköze. A korai segítségnyújtás a szociális kommunikációba ágyazottan történik meg. A gyermeknek meg kell tanulnia alkalmazkodni a tipikus közlési helyzetekhez, ezekben adekvátan kell tudnia együttműködni. Olyan beszédmagatartás kialakítására kell törekednünk, amely motiválja a gyermek közlési vágyát és felkelti a beszédkedvét. A gyermekben kialakult kapcsolattartási vágy a beszéd kialakulásának legföbb motiválója. A környezettől kapott nyelvi minta alapján történik meg a nyelv elsajátítása, melynek tudatosítása a családdal, az anyával a fejlesztő munka során kiemelt célunk. A beszéd tartalmi részének, a beszéd megértésének kialakítása, a hallásészlelés fejlesztése, a fonetikai tudatosság kialakítása, a gyermek beszédfejlettségéhez, életkorához, érdeklődéséhez igazodó játékos tevékenységeken, meséken keresztül történik meg.

\section{A kognitív funkciók fejlesztése}

A gondolkodás fejlődése szorosan összefügg a nyelv fejlődésével, a nyelv fejlődése viszont elősegíti a gondolkodás fejlődését. A kognitív funkciók fejlesztésekor különös figyelmet kell fordítanunk a tapasztalatszerzés, a cselekvés közbeni ismeret elsajátítására. Nemcsak egy adott készség megtanítása a célunk, hanem az is, hogy a megismerő tevékenység folyamatába a kialakított készség beépüljön, így alapját képezhesse további megismerésnek. A játékos, sokoldalú tapasztalatszerzés és megfigyelés a felfedezés örömével ajándékozza meg a gyermeket, és fejleszti kreativitását. A valóság felfedezése és felfedeztetése során a gyermekek pozitív viszonyba kerülnek környezetükkel, megismerik a környezet formai, téri, mennyiségi viszonyait, színeit. Fejlődik tájékozódó képességük, időérzékelésük, kialakulnak a nagysági és mennyiségi relációk, dinamikusan fejlődik a szókincsük, közlési vágyuk. 


\section{Tanácsok szülőknek}

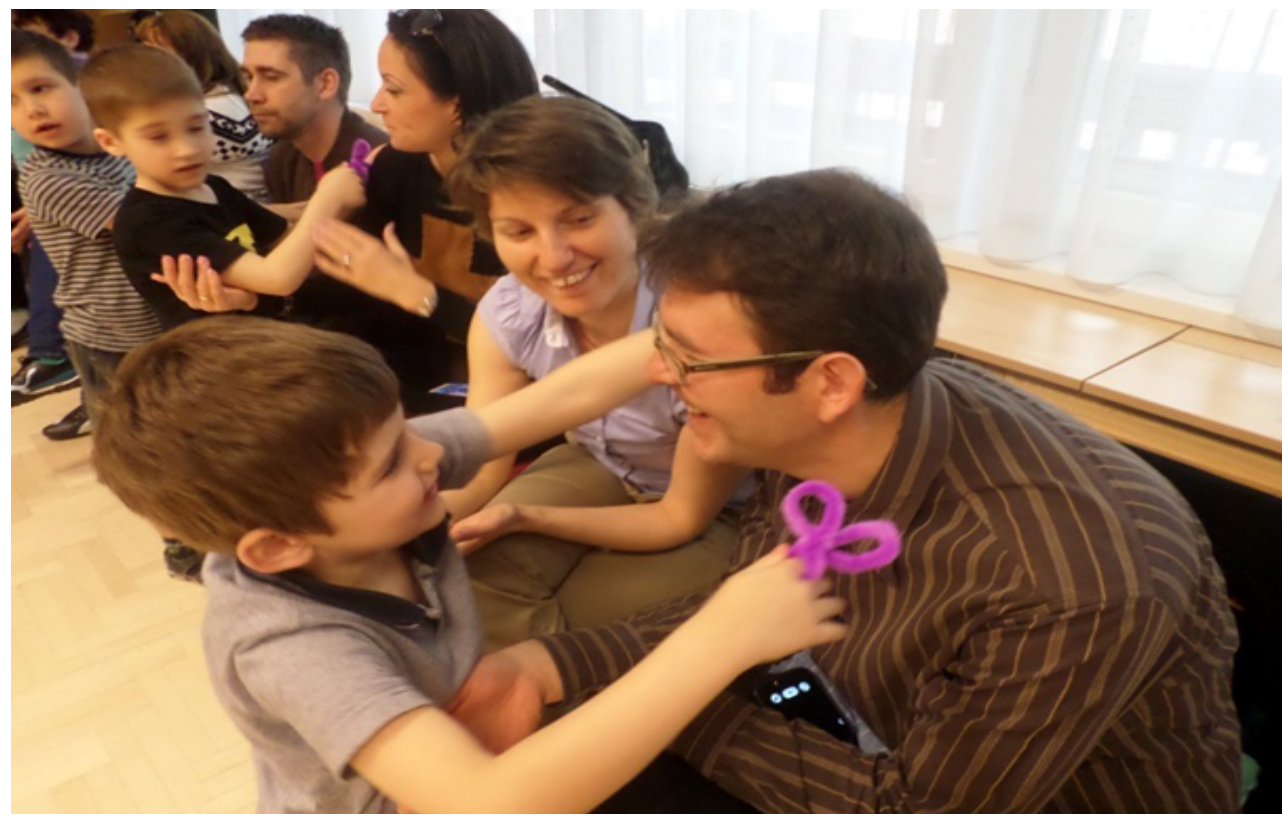

3. kép: Családi kommunikáció mondókázással

A nyelvi produkciós rendszer a korai évektől kezdve a felnőtt minta alapján szerveződik. A család, kiváltképpen az anya nagymértékben hozzájárulnak a gyermek beszédfejlődéséhez, a nyelvi hátrányok leküzdéséhez. Ennek tudatában fontosnak gondolom, hogy:

- Adjanak jó beszédmintát, vagyis lassan, tagoltan és érthetően beszéljenek gyermekükhöz, kerüljék a gügyögést!

- A gyermek közléseit türelmesen hallgassák végig!

- Ösztönözzék gyermeküket arra, hogy beszéljen (pl. kísérje beszéddel a gyermek cselekvéseit az öltöztetés és a közös játék során)!

- Meséljenek sokat a gyermeküknek, tanítsanak neki verseket és dalokat az életkorának megfelelően válogatva!

- A szülők adjanak helyes visszajelzéseket a gyermek beszédéről, ezzel is segítve a szókincs bővülését, a mondatalkotási készség és grammatikai rendszer fejlődését!

- Ne a gyermek hibáit ismételgessék, hanem a hibákat kijavítva folytassák az elkezdett beszélgetést!

- A gyermek hibás beszédét ne kritizálják!

- Biztosítsanak a gyermeküknek olyan következetes napirendet, amelyben a rendszeresen ismétlődő tevékenységek segítik a gyermek eligazodását szűkebb környezetében.

\section{Mikor forduljanak a szülők a logopédushoz?}

- Amennyiben a csecsemőkori gőgicsélést nem váltja fel gagyogás, vagy a gyermek gagyogása néhány hét alatt leépül, kifejezéstelenné válik.

- Ha a gyermek beszéde 2-2,5 éves koráig nem indul meg, és szókincse nem éri el az ebben az életkorban elvárható kb. ötven szót.

- Ha a későn megindult beszéd lassan fejlődik, és a beszédfejlődés megtorpan.

- Ha az artikuláció, a beszéd érthetősége 4-5 éves korra nem javul jelentősen, 8-10 hangot a gyermek még mindig hibásan ejt.

- Ha a gyermek sokszor hurutos, és nem figyel a beszédre, torzítja a hangokat.

- Ha a környezet ingereire nem vagy nem adekvátan reagál. 


\section{Eltérő beszédfejlődésű gyermekek a bölcsődében}

A gyermekek egy része azonban nem családban, hanem bölcsődei közösségben nevelkedik. Ebben az esetben az ott dolgozó szakemberek felelőssége is, hogy észrevegyék a gyermek eltérő beszédfejlődését. Az eltérő beszédfejlődésű gyermek a kortárs csoportban nem tud kommunikálni az életkori elvárásoknak megfelelően, így a mimika, a gesztusok és a helyzet alapján próbál meg tájékozódni a környezetében. A gyermek beszédében sok „dajkanyelvi” kifejezés marad vissza, gyakori a gesztusokkal való kommunikálás, a halandzsázás vagy az érzelmi töltetủ szavakkal történő kifejezés (pl. puff, nem-nem, hoppá). A meginduló beszéd nagyon nehezen érthető a több hangra kiterjedő hibás ejtés miatt (pl. villamos = vimmajos). Gyakran előfordul, hogy a beszédfejlődés elmaradása együtt jár a lassúbb ütemű mozgásfejlődéssel, amely mind a nagymozgások területén (pl. bizonytalan járás, nem tud kúszni, mászni), mind a finommozgások területén (pl. bizonytalan kanálfogás) megfigyelhető. A megkésett beszédfejlődésü gyermekek fáradékonyabbak, nehezebb számukra a környező világ ingereinek befogadása, így magatartási problémák jelenhetnek meg náluk a kapcsolatteremtés nehézségei miatt (pl. agresszív vagy visszahúzódó viselkedés). A gyermekekkel foglalkozó szakember kötelessége, hogy minden esetben felhívja a szülő figyelmét az általa észlelt problémára.

\section{Összegzés}

Ahogy láthattuk, a gyermek anyanyelv-elsajátítása a születés pillanatától - egyes kutatások szerint már a magzati lét utolsó fázisában - kezdődő folyamat, amely sikeres lezárulásában nagyon sok tényező játszik aktív szerepet. Ahhoz, hogy a kisgyermek megfelelö nyelvi fejlettséggel kezdhesse meg iskolai tanulmányait mindenképpen szükséges, hogy az esetleges nyelvi fejlődés zavarait a szakemberek, illetve szerencsésebb esetben a szülök is felismerjék, hogy azután együttes munkával küszöbölhessék ki a felmerülő problémákat. Ebben a szakemberek megfigyelése és szakszerü állapotfelmérése mellett szükség van arra is, hogy irányításukkal a szülök is mindent megtegyenek a nyelvi hátrányok megszüntetése érdekében.

\section{Irodalom}

Austin, John L. (1990): Tetten ért szavak. Akadémiai Kiadó, Budapest.

Fehérné Kovács Zsuzsanna és Sósné Pintye Mária (2010): Játsszunk beszédet! Sanoma Kiadó, Budapest.

Gósy Mária (2007): Az anyanyelv elsajátitás folyamatairól. In: Gósy Mária (szerk.): Beszédészlelési és beszédmegértési zavarok az anyanyelv-elsajátitásban. Nikol Kkt., Budapest, 8-17.

Gósy Mária és Gráf Rózsa (1998): Beszélgessünk a kisbabával! Nikol Gmk Kiadó, Budapest.

Lukács Ágnes és Kas Bence (2011): Érts és értesd meg magad! - A nyelvi fejlődés folyamata és elmaradásai. In: Balázs István (szerk.): A koragyermekkori fejlódés természete - fejlödési lépések és kihívások. Biztos Kezdet Kötetek II. Nemzeti Család- és Szociálpolitikai Intézet, Budapest, 180-224.

Rosta Katalin (2006): A beszéd-rendellenességek korai felismerése, fejlesztési lehetőségek. A nyelv és beszéd. In: Várkonyi Ágnes (szerk.): Ismerj meg ... Hogy megérts! - Ismeretek a sajátos nevelési igényü gyermekeket gondozó és nevelő szakemberek és családok részére. Semmelweis Egyetem Egészségügyi Főiskolai Kar, Budapest, 163-201. 


\section{A témához kapcsolódó ajánlott olvasmányok}

Borbély Sjoukje (2012): A szülök és mi. Budapesti Korai Fejlesztő Központ, Budapest. Heldstab, H. (2013): Miért nem beszél a gyermekem? ELTE Bárczi Gusztáv Gyógypedagógiai Kar, Budapest.

Németh Erzsébet és S. Pintye Mária (2002): Mozdul a szó... - Súlyosan akadályozott beszédfejlődésü gyerekek korai integratív fejlesztése. Logopédiai Kiadó, Budapest.

Rosta Katalin (2005, szerk.): Add a kezed! - A mentális fejlődés segitése sajátos nevelési igényü gyermekeknél. Logopédiai Kiadó, Budapest.

Rosta Katalin - Schuchné Rumpli Henriette (2007): Beszédfogyatékos gyermekek beszédpercepciós vizsgálata. In: Gósy Mária (szerk.): Beszédészlelési és beszédmegértési zavarok az anyanyelv-elsajátításban. Nikol Kkt., Budapest, 137-148.

Sósné Pintye Mária és Melegné Steiner Ildikó (2007): Percepciós zavarok korai felismerése és terápiája a beszédindító korai intervencióban. In: Gósy Mária (szerk.): Beszédészlelési és beszédmegértési zavarok az anyanyelv-elsajátításban. Nikol Kkt., Budapest, 312-322.

Szelényi Marianna (2006, szerk.): Apró lépések - Korai fejlesztő program lassabban fejlődő gyermekek és szüleik számára. Budapesti Korai Fejlesztő Központ, Budapest. 